\title{
Is sequential feeding a suitable technique to compensate for the negative effects of a tropical climate in finishing broilers?
}

\author{
Carlos LOZANO $^{\mathrm{a}}$, Vasco De BASILIO ${ }^{\mathrm{a}}$, Ingrid Oliveros ${ }^{\mathrm{b}}$, \\ Ramon AlVAREZ ${ }^{\mathrm{a}}$, Irina COLINA ${ }^{\mathrm{a}}$, Denis BASTIANELLI ${ }^{\mathrm{c} *}$, \\ Shlomo YAHAV ${ }^{\mathrm{d}}$, Michel PICARD \\ a Instituto de Produccion Animal, Facultad de Agronomia, Universidad Central De Venezuela, \\ Apdo. 4579, Maracay 2101, Venezuela
$\mathrm{b}$ Instituto de Investigaciones Zootechnicas, Instituto Nacional de Investigaciones Agropecuarias, \\ Apdo. 4653, Maracay 2101, Venezuela \\ c Élevage et Médecine Vétérinaire, Centre de Coopération Internationale en Recherche \\ Agronomique pour le Développement, Campus International de Baillarguet, TA 30/A, \\ 34398 Montpellier Cedex 5, France \\ d Institute of Animal Science, Agricultural Research Organization, The Volcani Center, \\ PO Box 6, Bet Dagan 50250, Israel \\ e Institut National de la Recherche Agronomique-Station de Recherches Avicoles, 37380 Nouzilly, \\ France
}

(Received 9 May 2005; accepted 20 October 2005)

\begin{abstract}
Feed withdrawal during the warmest part of the day (09:00 to 16:00 h) was compared with the distribution of ground corn and commercial feed consumed ad libitum by control broilers from 28 to $42 \mathrm{~d}$ exposed to tropical climatic conditions (averaged $\mathrm{Ta}=25^{\circ} \mathrm{C}$; Relative Humidity $(\mathrm{RH})=72 \%$ ). From 16:00 to 09:00 h, a continuous illumination was in the poultry shed and the chickens received a commercial diet. Each diet was supplied to 7 pens of 14 unsexed broilers. Both feed withdrawal and corn distribution during the day period reduced growth $(P<0.01)$ and deteriorated feed conversion $(P<0.01)$ compared to the ad libitum control. At the age of $41 \mathrm{~d}$, the average body temperature $(\mathrm{Tb})$ at $14: 00 \mathrm{~h}$ in the control group was $42.56{ }^{\circ} \mathrm{C}$. It was higher $(P<0.002)$ than that recorded in the corn fed group $\left(42.27^{\circ} \mathrm{C}\right)$ and the feed withdrawal chickens $\left(42.11^{\circ} \mathrm{C}\right)$. These effects measured in 4-6 week-old broilers exposed to a moderate tropical climate, illustrate the limitation of feed restriction and sequential feeding under practical conditions. Further research is needed to study the diurnal distribution of corn or feed withdrawal coupled with a balanced diet richer in essential amino acids than the commercial diet during the nocturnal period.
\end{abstract}

broiler / body temperature / sequential feeding / rhythm / warm climate

Résumé - $L$ 'alimentation séquentielle est-elle une technique utilisable pour compenser les effets négatifs d'un climat tropical chez les poulets de chair en finition? Le retrait de l'aliment pendant

* Corresponding author: denis.bastianelli@cirad.fr 
les phases les plus chaudes de la journée (09:00 à 16:00 h) a été comparé à la distribution ad libitum de maïs broyé ou d'un aliment commercial pendant la même période, chez des poulets de chair élevés en milieu tropical (Température moyenne $=25^{\circ} \mathrm{C} ; \mathrm{HR}$ moyenne $=72 \%$ ) entre 28 et 42 jours d'âge. Entre 16:00 et 09:00 h tous les poulets recevaient l'aliment commercial ad libitum et le poulailler était continuellement éclairé. Chaque régime expérimental a été distribué à 7 parquets de 14 poulets non sexés. Le retrait d'aliment comme la distribution de maïs ont réduit la croissance $(P<0,01)$ et détérioré l'indice de consommation $(P<0,01)$ par rapport aux témoins nourris ad libitum. A l'âge de 41 jours, la température corporelle moyenne mesurée à $14: 00 \mathrm{~h}$ était de $42,56^{\circ} \mathrm{C}$ chez les témoins. Elle était supérieure $(P<0,002)$ à celle mesurée chez les poulets recevant du maïs $\left(42,27^{\circ} \mathrm{C}\right)$ ou mis à jeun $\left(42,11^{\circ} \mathrm{C}\right)$. Ces effets mesurés entre 4 et 6 semaines d'âge chez des poulets exposés à un climat tropical modéré, illustrent les limites du retrait de l'aliment ou l'alimentation séquentielle dans des conditions pratiques. Des recherches complémentaires associant à la distribution de maïs ou au jeûne diurne, un régime complémentaire nocturne plus riche en acides aminés indispensables que le régime commercial sont souhaitables.

poulet de chair / température corporelle / alimentation séquentielle / rythme / climat chaud

\section{INTRODUCTION}

A major limiting factor of the development of broiler production in tropical areas is the higher mortality after the age of 4 weeks in the warmest part of the year. For instance, in Venezuela at the end of the dry season, temperatures higher than $35^{\circ} \mathrm{C}$ in poultry sheds may be responsible for the mortality of up to $10 \%$ of 5 to 6 week-old broilers. Feed restriction during the warmest part of the day limits mortality due to heat outbreaks but reduces growth even if light and feed are provided ad libitum during the night $[6,9]$. A practical observation has demonstrated that broiler chickens are hungry when feed is given back (especially in cooler days) and the areas of the feeders are overcrowded, which may result in some mortality.

A dual feeding program alternating a low protein feed during the warm day and a high protein diet during the cooler night reduces mortality in broilers challenged by artificial heat stress during the finishing period [2]. A practical application of this technique would be to feed a pure cereal during the day-period and a complete commercial feed at night. The aim is to induce conditions where the bird consumes less feed during the daytime while maintaining a minimum intake to avoid a rush at re-feeding time. The cereal in this study was ground because a large particle size of the diet may stimulate intake [11].

The aim of the present experiment was to evaluate the effect of distribution of ground corn during the daytime (09:00 to 16:00 h) on growth and body temperature (Tb) of broiler chickens from 4 to 6 weeks of age in a tropical climate, and to compare it to two control treatments: a commercial feed given ad libitum during the daytime and nighttime or only during the nighttime, with the feed being withdrawn during the daytime.

\section{MATERIALS AND METHODS}

\subsection{Experimental procedures}

The experiment was held in an open poultry shed of the Institute of Animal Production in Maracay, Venezuela. Twentyone floor pens $\left(2 \times 2 \mathrm{~m}^{2}\right)$ were equipped with rice hull bedding material, one drinker, two feed troughs and one lamp $(75 \mathrm{~W})$ per pen. Continuous illumination was adopted during the experiment. At $21 \mathrm{~d}$ of age, 294 broiler chickens (Cobb 500- not sexed) were randomly assigned to the 21 pens ( 14 chickens per pen). From 21 to $28 \mathrm{~d}$ of age, the chickens were adapted to their new pen environment with the same commercial feed provided ad libitum to all. From 28 to 

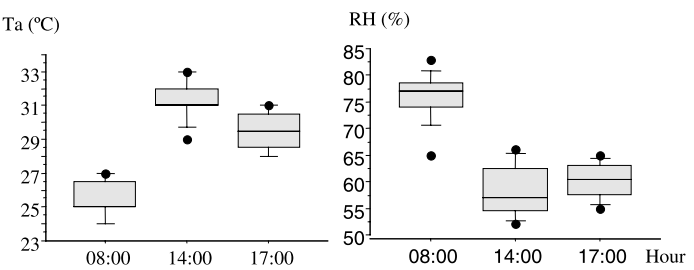

Figure 1. Box plot of the environmental temperature (Ta) and Relative Humidity $(\mathrm{RH})$ measured in the poultry shed at 08:00, 14:00 and 17:00 $\mathrm{h}$ during the experimental period (28-41 d).
41 days of age, three different treatments were applied to 7 pens of each treatment. A control group (T1) received a commercial corn / soybean meal finisher diet ad libitum containing $3200 \mathrm{kcal} \mathrm{ME} ; 195 \mathrm{~g} \mathrm{CP} ; 10.3 \mathrm{~g}$ lysine; $7.6 \mathrm{~g}$ methionine + cystine per $\mathrm{kg}$. A second group (T2) received the same feed from 16:00 $\mathrm{h}$ to $9: 00 \mathrm{~h}$ but the feed was withdrawn from 09:00 to $16: 00 \mathrm{~h}$. In the third treatment (T3), chickens received pure ground corn supplying $3350 \mathrm{kcal} \mathrm{ME}$; 92 g CP; 2.5 g lysine; 3.8 g methionine + cystine per kg, during the day period (09:00 to $16: 00 \mathrm{~h}$, corresponding to the withdrawal period of T2) and the commercial feed during the night. The spatial distribution of the treatment in pens followed a 7 randomized block design.

\subsection{Measurements}

Ambient temperature (Ta) and relative humidity $(\mathrm{RH})$ were measured daily at 08:00, 14:00 and 18:00 $\mathrm{h}$ in one pen for each treatment. Body temperatures $\left(\mathrm{T}_{\mathrm{b}}\right)$ of all broilers were measured by blocks at 35 and $41 \mathrm{~d}$ of age starting at 14:00 h (warmer period) and lasted two hours. Body temperature was measured with a probe connected to a rapid thermometer Testo $110(\mathrm{GmbH}$ \& Co D 79853 Lenzkirch, Germany), calibrated to a range of 0 to $60{ }^{\circ} \mathrm{C}$ with precision of $0.1{ }^{\circ} \mathrm{C}$. The probe was inserted $4 \mathrm{~cm}$ into the distal colon, immediately after the chickens were individually gently handled [3]. The mortality of the chickens was recorded daily. All chickens were individually weighed at 28 and $41 \mathrm{~d}$ of age. Food intake per pen was measured daily for each period of distribution.

\subsection{Statistical analyses}

One way ANOVA were applied to evaluate the effect of the treatments and the pen was the experimental unit (pen = replication). Block effects were computed and deleted when the variance ratio was $<1$. Covariance analyses using the body weight at 28 days of age were assayed and the results are presented when the covariate effect reached significance. The treatment means were tested by the multiple comparison test of Student, Newmann and Keuls. The results were significantly different when $P<0.05$.

\section{RESULTS}

\subsection{Ta and RH variations during the experimental period}

The measured temperatures during the experimental period were relatively moderate and never exceeded $33^{\circ} \mathrm{C}$ (Fig. 1). In the morning, Ta averaged $25^{\circ} \mathrm{C}$ and $\mathrm{RH} 76 \%$. Maximal Ta $\left(31^{\circ} \mathrm{C}\right)$ was attained at $14: 00 \mathrm{~h}$ and was reduced by $2{ }^{\circ} \mathrm{C}$ at 17:00 h. Corresponding RH were 57 and $62 \%$, respectively.

\subsection{Food intake, body weight, and $\mathbf{T b}$}

No mortality was observed during the experimental period. Body weight at $28 \mathrm{~d}$ of age was not different among treatments $(P>0.1)$. If the body weight at $28 \mathrm{~d}$ of age was taken as a covariate, it only significantly affected the body weight at $41 \mathrm{~d}$ but the adjusted means $(\mathrm{T} 1=1964, \mathrm{~T} 2=1839$ 
Table I. Mean body weight, food intake, feed conversion and body temperature (Tb) of broilers during the experimental period $(28-41 \mathrm{~d}$ of age $) . \mathrm{T} 1=$ control, $\mathrm{T} 2=$ starved during the day period, $\mathrm{T} 3=$ fed mash corn during the day period ( $\mathrm{N}=7$ pens of 14 chickens).

NS $=$ not significant $(P>0.05)$.

\begin{tabular}{lccccc}
\hline & $\mathrm{T} 1$ & $\mathrm{~T} 2$ & $\mathrm{~T} 3$ & $P<$ & $\mathrm{SEM}$ \\
\hline Body Weight at 28 d (g per bird) & 1014 & 977 & 1010 & $\mathrm{NS}$ & 13 \\
Body Weight at 41 d (g per bird) & $1984 \mathrm{a}^{*}$ & $1803 \mathrm{~b}$ & $1849 \mathrm{~b}$ & 0.01 & 32 \\
Body Weight gain 28-41 d (g per bird) & $970 \mathrm{a}$ & $826 \mathrm{~b}$ & $839 \mathrm{~b}$ & 0.01 & 25 \\
Food intake 9:00-16:00 h (g per bird) & $589 \mathrm{a}$ & 0 & $336 \mathrm{~b}$ & 0.001 & 26 \\
Food intake 16:00-9:00 h (g per bird) & $1279 \mathrm{c}$ & $1759 \mathrm{a}$ & $1433 \mathrm{~b}$ & 0.001 & 36 \\
Total food intake (g per bird) & 1869 & 1759 & 1769 & $\mathrm{NS}$ & 34 \\
Feed conversion $(\mathrm{g}$ per g) & $1.92 \mathrm{~b}$ & $2.14 \mathrm{a}$ & $2.12 \mathrm{a}$ & 0.01 & 0.04 \\
Tb at 35 d $\left({ }^{\circ} \mathrm{C}\right)$ & $41.94 \mathrm{a}$ & $41.56 \mathrm{~b}$ & $41.68 \mathrm{~b}$ & 0.001 & 0.05 \\
Tb at 41 d $\left({ }^{\circ} \mathrm{C}\right)$ & $42.56 \mathrm{a}$ & $42.11 \mathrm{~b}$ & $42.27 \mathrm{~b}$ & 0.002 & 0.07 \\
\hline
\end{tabular}

* Means followed by different superscript are significantly different $(P<0.05)$.

and $\mathrm{T} 3=1835 \mathrm{~g}$ per bird) exhibited exactly the same significant differences as in the ANOVA presented Table I. Broilers that consumed ground corn during the day gained less weight $(P<0.01)$ from 28 to $41 \mathrm{~d}$ compared to the ad libitum fed control and did not differ from the diet withdrawal group (Tab. I). The amount of corn diet consumed was on average $57 \%$ of that of the consumption of the commercial diet during the same period. This proportion did not vary throughout the experiment (Fig. 2). During the night, feed compensation was observed in the withdrawal treated broilers who consumed more feed $(P<0.01)$ from 16:00 to 09:00 $\mathrm{h}$ than the corn fed broilers, and more than the ad libitum controls (Tab. I). The total feed consumption (during $24 \mathrm{~h}$ ) was not significantly different among the treatments. However T1 ate on average numerically more than $\mathrm{T} 2$ and $\mathrm{T} 3$ $(P<0.10)$. Feed conversion was deteriorated $(P<0.01)$ by both feed withdrawal and corn distribution treatments compared to the ad libitum control one (Tab. I).

Both feed withdrawal and corn distribution treated broilers demonstrated a reduction in $\mathrm{Tb}(P<0.002)$ at 35 and $41 \mathrm{~d}$ of age compared to the ad libitum controls (Tab. I).
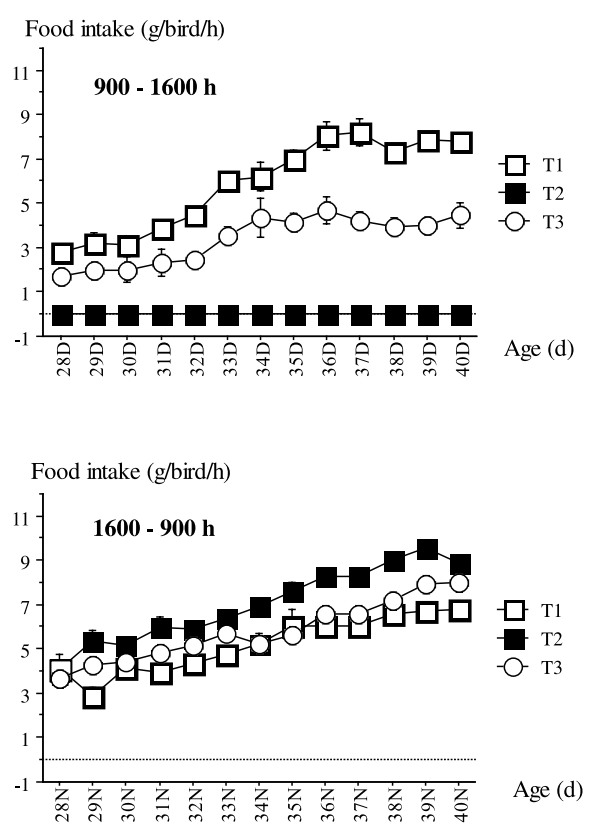

Figure 2. Hourly average food intake per chicken (SE) of the three treatment groups during the day (09:00 to 16:00 h) and the night $(16: 00$ to $09: 00 \mathrm{~h})$ periods from 28 to $40 \mathrm{~d}(\mathrm{n}=$ 7 pens of 14 broilers). T1 = ad libitum fed a commercial feed day and night; $\mathrm{T} 2=$ fed a commercial feed at night only; $\mathrm{T} 3=$ fed a commercial feed at night and pure corn during the day. 


\section{DISCUSSION}

The results of this experiment illustrate one of the main difficulties of the feed restriction technique in tropical climates. Depending on the actual temperature endured by the chickens, the technique may have positive $[10,5]$ or negative (present work) effects on growth and feed conversion. In general when the environmental conditions induce mortality (i.e., $\mathrm{Ta}>33^{\circ} \mathrm{C}$ for several hours during several consecutive days and $\mathrm{Tb}$ of some birds overpasses $44^{\circ} \mathrm{C}$, above which level survival is compromised) the feed withdrawal techniques show positive effects on overall performances. Under the present conditions, no mortality was observed and the control chickens consumed hourly more feed during the daytime than at nighttime. This demonstrates the non limiting warm conditions for feed consumption, despite the fact that the experiment was done during the dry season (warmest part of the year in Venezuela). However, Tb was significantly reduced at $14: 00 \mathrm{~h}$ both by feed withdrawal or provision of pure corn, suggesting that both treatments, at least partly, alleviate heat stress $[3,4,12]$. Interestingly, $\mathrm{Tb}$ did not increase significantly by the distribution of corn compared to feed withdrawal.

Broilers starved during the warmest part of the day (T2) were able to compensate, but not completely, by increasing intake during the nighttime, corresponding to the cooler part of the day. A similar observation was made with pigs subjected to high temperature [7]. The nocturnal food intake measured values suggested that food intake was mainly based on energy balance. Chickens ate the same overall energy amount whether they received corn or nothing during the day period and did not compensate for the lower amino acid intake induced by corn by eating more feed at night. Broilers eating corn had therefore an overall lower essential amino acid intake than the two controls. This could be compensated for by using a sequential feeding technique with a nocturnal diet richer in amino acids than the commercial feed used here to balance the overall amino acid daily intake of broilers [2]. A low protein nocturnal diet relatively rich in essential amino acids might even improve the energy intake as suggested by studies in the pig [8]. The overall amino acid balance seems to be a condition of success of the sequential feeding program under neutral temperature [1].

\section{CONCLUSION}

Starving broilers or providing them ground corn during the warmest part of the day is associated with a decrease in performance under moderate tropical conditions, but helps to alleviate, at least partly, heat stress by reducing body temperature. Further research is needed with a complementary diet richer in essential amino acids than the commercial diet during the nocturnal period.

\section{ACKNOWLEDGMENTS}

The authors thank the personal of the poultry section of the Instituto de Produccion Animal for their help in the practical realization of this work and the Department of Agro climatology of the Instituto Nacional de Investigaciones Agropecuarias for the measures of the environment during the experiment. This program was partly supported by the ECOS cooperation program between Venezuela and France.

\section{REFERENCES}

[1] Bouvarel I., Barrier-Guillot B., Larroude P., Boutten B., Leterrier C., Merlet F., Vilariño M., Roffidal L., Tesseraud S., Castaing J., Picard M., Sequential feeding programs for broiler chickens: twenty-four- and fortyeight-hour cycles, Poult. Sci. 83 (2004) 49-60.

[2] De Basilio V., Vilariño M., Yahav S., Picard M., Early-age thermal conditioning and a dual feeding program for male broilers challenged by heat stress, Poult. Sci. 80 (2001) 29-36.

[3] De Basilio V., Requena F., Leon A., Vilariño M., Picard M., Early-age thermal conditioning immediately reduces body temperature of 
broiler chicks under a tropical environment, Poult. Sci. 82 (2003) 1235-1242.

[4] Lott D., The effect of feed intake on body temperature and water consumption of male broilers during heat exposure, Poult. Sci. 70 (1991) 756-759.

[5] Ozkan S., Akbas Y., Atlan O., Atlan A., Ayhan V., Ozkan K., The effect of short-term fasting on performance traits and rectal temperature of broilers during the summer season, Br. Poult. Sci. 44 (2003) 88-95.

[6] Picard M., Sauveur B., Fenardji F., Angulo I., Mongin P., Ajustements technico-économiques possibles de l'alimentation des volailles dans les pays chauds, INRA Prod. Anim. 6 (1993) 87-103.

[7] Quiniou N., Renaudeau D., Dubois S., Noblet J., Effect of diurnally fluctuating high ambient temperatures on performances and feeding behaviour of multiparous sows, Anim. Sci. 71 (2000) 571-575.
[8] Renaudeau D., Noblet J., Quiniou N., Dubois S., Influence de l'exposition au chaud et de la réduction du taux de protéines dans l'aliment sur les performances des truies multipares en lactation, Journées de la Recherche Porcine en France 33 (2001) 181-187.

[9] Teeter R., Optimizing production of heat stressed broilers, Poult. Digest. 94 (1994) 1027.

[10] Yalcin S., Ozkan S., Turkmut L., Siegel P.B. Responses to heat stress in commercial and local broiler stock performance traits, $\mathrm{Br}$. Poult. Sci. 42 (2001) 149-152.

[11] Yo T., Siegel P.B., Guerin H., Picard M., Selfselection of dietary protein and energy by broilers grown under a tropical climate: effect of feed particle size on the feed choice, Poult. Sci. 76 (1997) 1467-1473.

[12] Zhou W., Yamamoto S., Effects of environmental temperature and heat production due to food intake on abdominal temperature, shank skin temperature and respiration rate of broilers, Br. Poult. Sci. 38 (1997) 107-114. 